\title{
Space-planning solutions of the Quaker meetings house in Russia
}

\author{
Evgeny Orlov*
}

Moscow State University of Civil Engineering, Yaroslavskoe shosse, 26, Moscow, 129337, Russia

\begin{abstract}
Quakers are a Protestant trend in Christianity that was formed in England during the English bourgeois revolution. The peculiarities of this direction include the fact that Quakers hold prayer meetings for communion with God not in churches, but in fact, in ordinary rooms called Quaker Meeting Houses. At present, there is practically no research on the development of space-planning solutions for Quaker meetings houses, including developments in the design of engineering equipment for such types of buildings. Information was collected and analyzed on the need to design specific premises for comfortable holding of Quaker prayer meetings. The analysis was carried out according to the following criteria: the total area of the objects of the Quaker prayer meeting; availability of basic meeting rooms; availability of auxiliary premises; necessary engineering equipment; architectural and urban planning appearance of the building (including the building facades); urban planning situation, taking into account the improvement of territories. There were developed blocklayout diagrams of premises for various functional purposes, a variant of space-planning solutions of a house for holding prayer meetings of Quakers in Russia, a draft proposal for its architectural appearance, as well as options for various systems of engineering equipment of buildings to ensure high comfort requirements.
\end{abstract}

\section{Introduction}

Quakers, also called Friends, - a Protestant movement in Christianity, which was formed in England during the English bourgeois Revolution (1642-1649). The founder of this religious movement was George Fox (1624-1691) - an English craftsman [1]. Today, Quakerism has approximately 377 thousand people around the world, including representatives from Russia.

The classical Quakerism of the initial period assumed an appeal to God without any complicated conventions through silent prayer surrounded by friends. In order to remove any conventions and restrictions for communion with God, it was assumed that pastors and sermons would be completely abandoned in their pure form, as they are in other Protestant areas of Christianity. In addition, the Quakers do not recognize the sacred sacraments and articles of faith [1].

\footnotetext{
* Corresponding author: jeks-2003@yandex.ru
} 
At the heart of the Quaker faith is the concept of the inner light that is in every person. It is through him the direct communication with God is possible with the help of silent prayers.

The first representatives of the Quakers were poor. It was assumed that the faith should be accessible to all segments of the population without expensive rites and paid priesthood. This led to the fact that prayer meetings for communion with God could be held anywhere. Thus, the concept of the church, as is the case in the classical trends of Protestantism, Catholicism and Orthodoxy, is completely absent from the Quakers. Much later, traditional Quakerism underwent changes, and in some branches of this faith you can find churches for conducting divine services, including a return to pastoral service. The building of the church in its structure and in terms of space-planning solutions becomes similar to the churches of classical Protestantism, and in some cases completely duplicate them.

For holding prayer meetings in traditional (conservative) Quakerism, it is advisable to develop space-planning solutions for a prayer house that will fully meet all the requirements of comfort, meeting modern requirements of convenience.

To date, there is practically no research on the development of space-planning solutions for prayer houses for Quaker meetings, including developments in the design of engineering equipment for such types of buildings. There is a large amount of literature on the architecture of public buildings [2-6], as well as buildings of religious purpose [7-15], which provides not only recommendations on space-planning solutions, but also on the placement of the necessary engineering equipment. At the same time, there are only a few works devoted to the architecture and typology of buildings and places of worship for Quakers [16-20].

Figures 1-3 shows some of the most interesting examples of the exterior and interior of modern Quaker meetings houses.
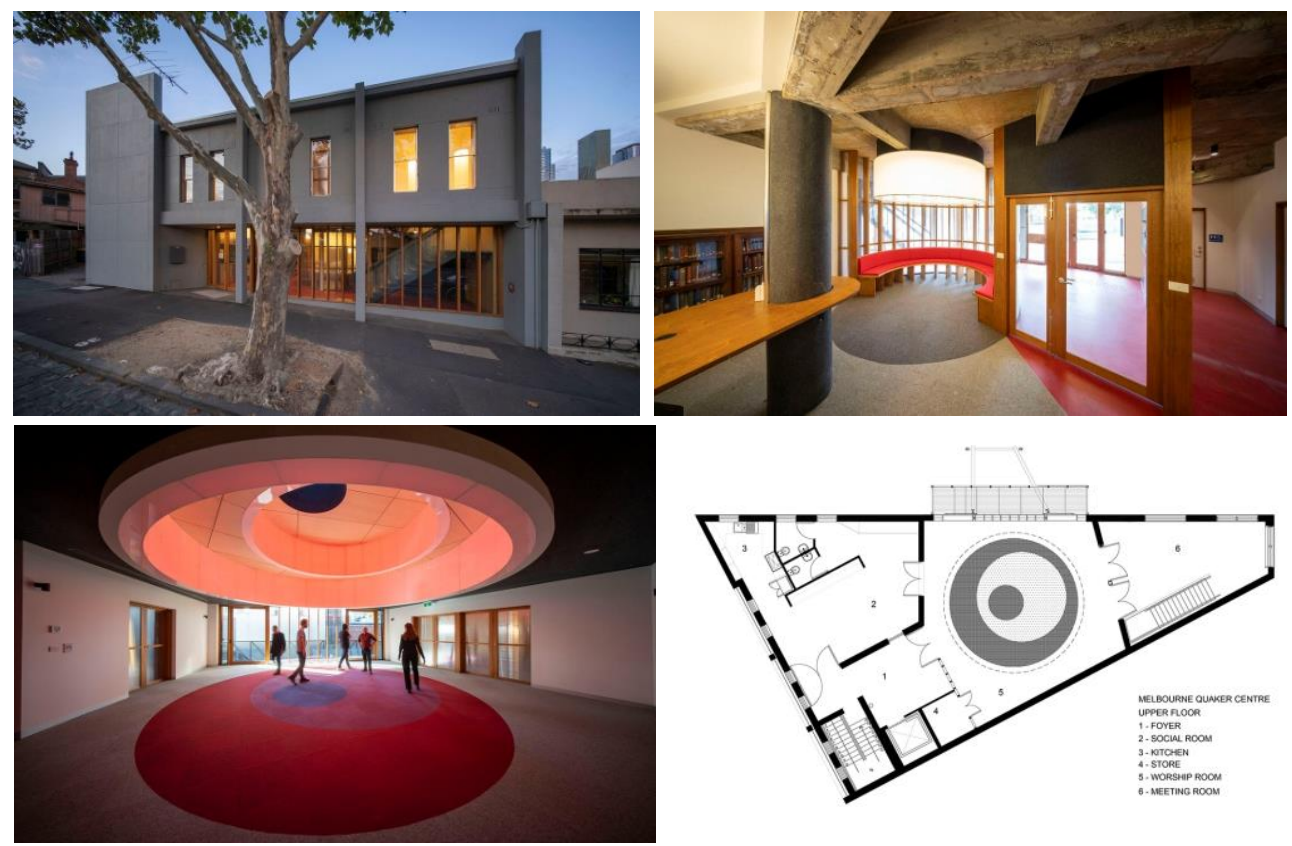

Fig. 1. Exterior and interior views and upper flow plan of Melbourne Quakers Center (Nervegna Reed Architecture + ph Architects). Source: https://www.archdaily.com/941390/melbourne-quakers-centernervegna-reed-architecture-plus-ph-architects 

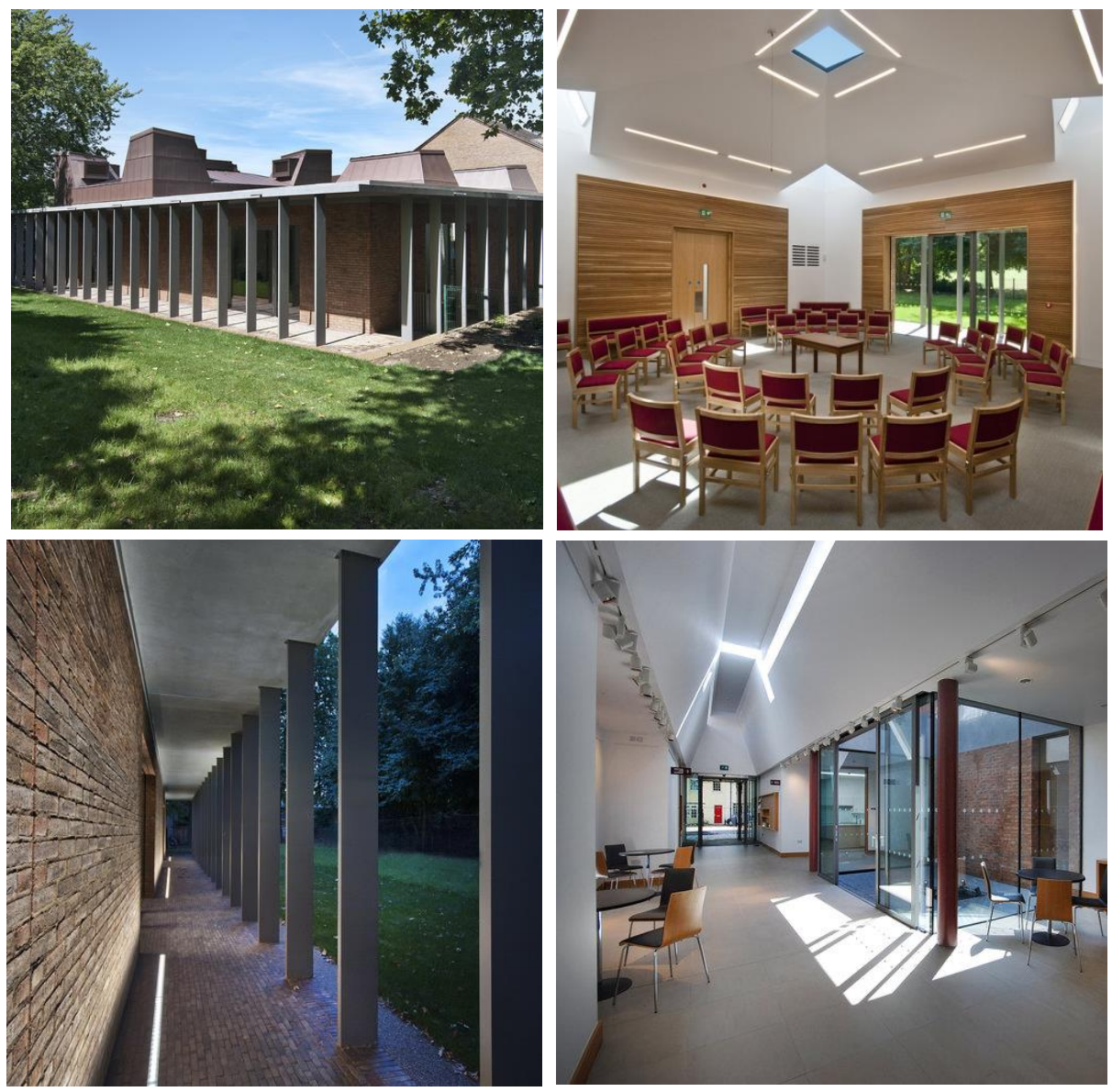

Fig. 2. Exterior and interior views of Kingston Quaker Centre, Fairfield East, Kingston upon Thames. Source: https://www.context-architecture.co.uk/kingston-quaker-centre1
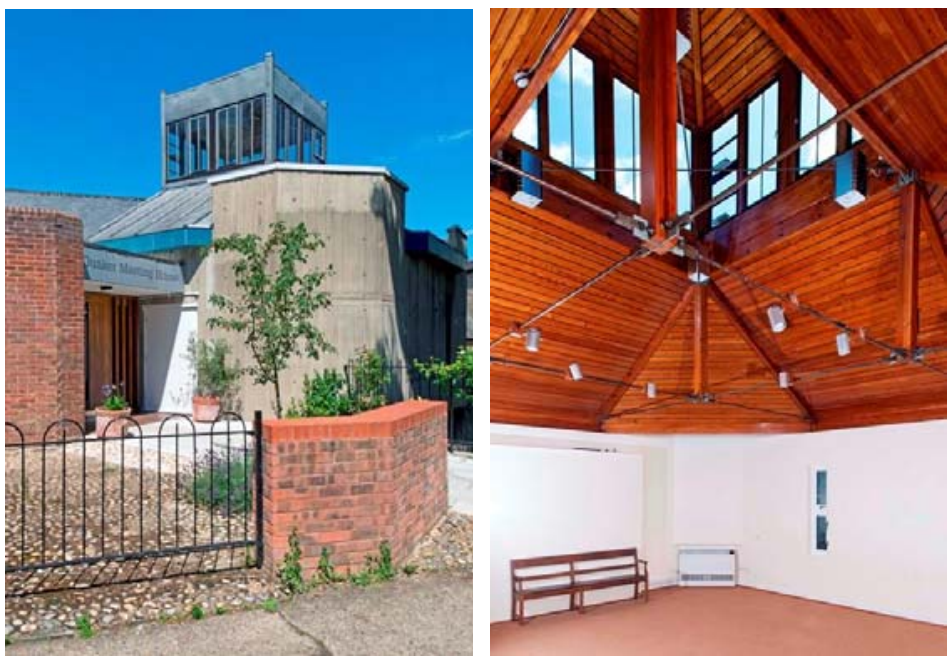

Fig. 3. Exterior and interior views of Trevor Dannat's Blackheath Meeting House, London, CHistoric England, Lucy Millson-Watkins, DP180135, DP180131.

Source: https://historicengland.org.uk/whats-new/research/back-issues/quaker-meeting-houses/ 
The author of the article sets himself the task of studying and deepening his knowledge not only on the development of space-planning solutions for the Quaker meeting house, but also on its engineering equipment, which will be necessary for its functioning.

The author of the article was faced with the task of studying and deepening knowledge on the development of space-planning solutions for the Quaker meeting house as well as on the design of engineering equipment of this building.

\section{Methods}

The author has repeatedly visited Quaker prayer meetings, where he collected information and analyzed the need for specific rooms for comfortable religious meetings. Special literature on the subject of Quakerism and sacral architecture was also studied [1, 7-20].

The author conducted the analysis according to the following criteria:

- total area of Quaker prayer meeting spaces;

- availability of main meetings rooms;

- availability of auxiliary facilities;

- the necessary engineering equipment;

- architectural and town-planning appearance of the building (including the facades of the building);

- urban planning situation, taking into account the improvement of territories.

Also, various types of engineering equipment were considered and analyzed, which make it possible to comfortably hold prayer meetings.

\section{Results}

As a result of the study, the following conclusions were made, which are given below to understand the entire existing problem.

Taking into account the fact that the number of parishioners at prayer meetings within one city in Russia does not exceed, as a rule, 10-12 people, a small area of the projected building should be planned, which will not exceed $100 \mathrm{~m}^{2}$. The prayer house is expected to have one floor with a pitched roof.

A layout diagram of premises (blocks) for various functional purposes, a variant of the space-planning solutions for the premises of Quakers meetings house as well as a draft proposal for its architectural appearance are presented in Figures 4, 5 and 6.

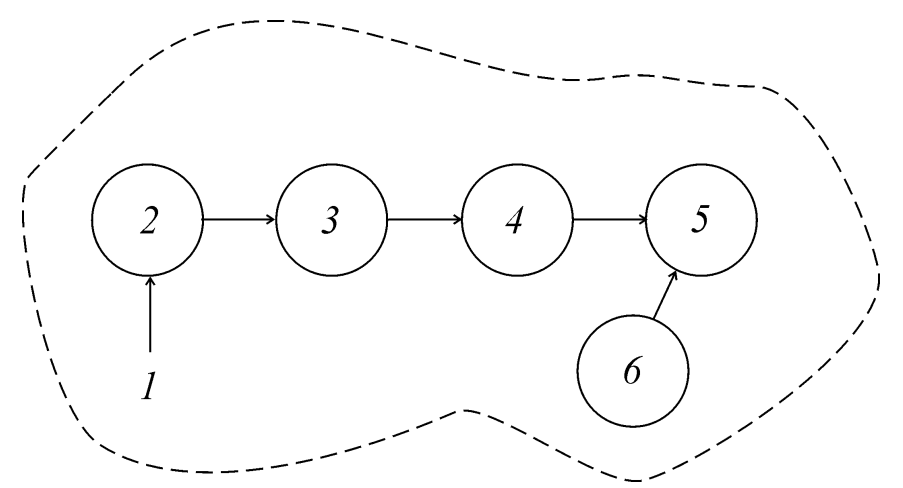

Fig. 4. The layout diagram of premises (blocks) for various functional purposes for Quakers meetings house: 1 - public spaces; 2 - block of premises of the entrance part; 3 - administrative premises and a block of household premises; 4 - the area for holding prayer meetings; 5 - food intake area; 6 - block of kitchen facilities 
The entire territory of the house is zoned into the following blocks, taking into account their functionality:

- block of premises of the entrance part;

- eating area;

- a block of kitchen facilities;

- administrative premises and a block of household premises;

- the area for holding prayer meetings.

A more rational location of this Quaker meeting house is a nearby suburb with private residential buildings not exceeding two floors. The house will be located on a plot of land on an area of 10 acres $\left(1000 \mathrm{~m}^{2}\right)$.

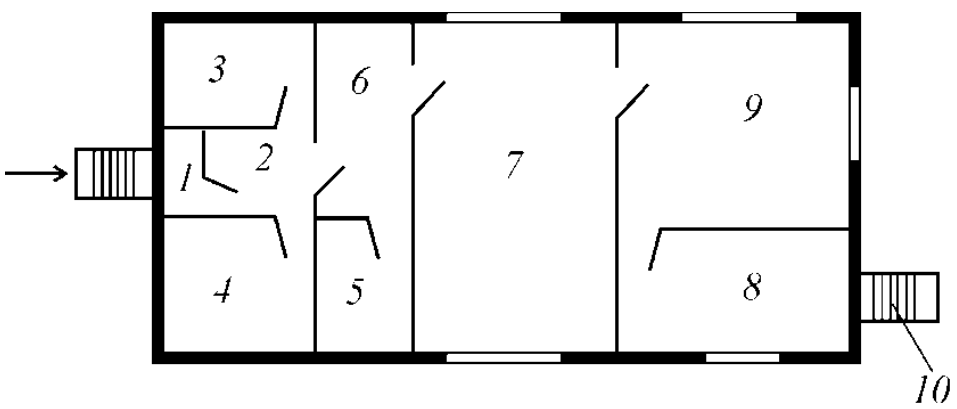

Fig. 5. Example of a space-planning solution of Quaker meetings house:

1 - vestibule; 2 - hall; 3 - wardrobe; 4 - bathroom room; 5 - staff rest room;

6 - administrative room; 7 - room for prayer meetings; 8 - kitchen area; 9 - eating area;

10 - exit from the building for staff (porch)

In the entrance part there will be a vestibule at the entrance, a hall and a dressing room for guests. A bathroom is also installed nearby.

The eating area is mandatory in such a house, because after prayer meetings, which last at least one hour, and ends with the shaking hands of parishioners, a small buffet table with a meal is meant for leisure.

The kitchen block is a kitchen area where food is prepared. It is also possible to deliver ready meals with their preheating in microwave ovens.

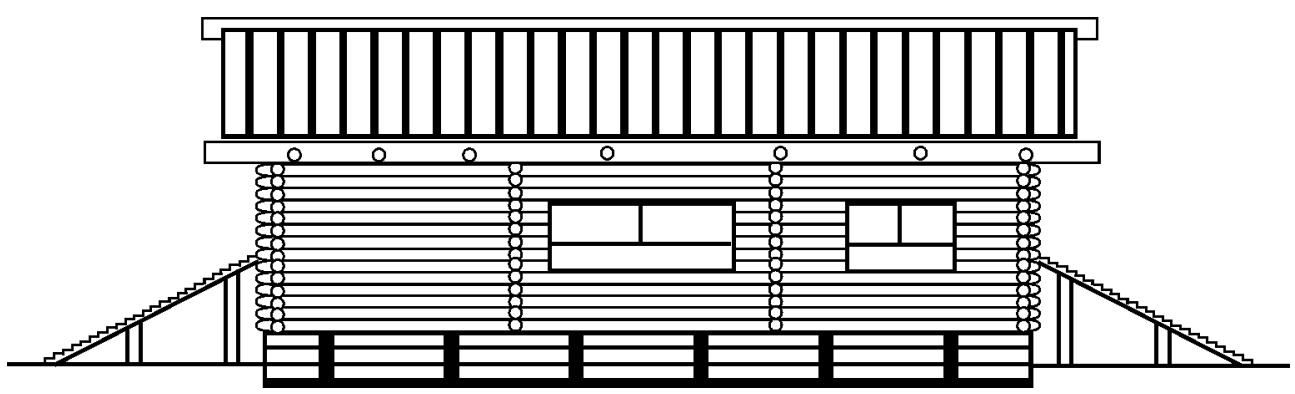

Fig. 6. Sketch proposal for the architectural appearance of Quaker meetings house.

Administrative premises - there is a place for the administrator of meetings house, where documentation and analysis of attendance are kept, and where guests can also be met. You should also provide a recreation area (areas), for example, not only for the service personnel, but also for the guards responsible for the safety of this house (Figure 5).

The prayer meeting area is the main space that defines the main function of this building. As mentioned earlier, prayer meetings are held for at least one hour in complete 
silence. If necessary, during the meeting or at the end of it, anyone can stand up and speak to the parishioners. People who come to prayer meetings sit on chairs that can be arranged either in a line or in a circle. A space of $30 \mathrm{~m}^{2}$ is enough to accommodate 10-12 seated parishioners.

Special attention should be paid to soundproofing the meeting area. The fact is that during prayers there should be complete silence inside and nothing outside should distract from the internal immersion in oneself for communication with God.

It should also be noted that the design of Quaker meetings house is not limited only to the development of space-planning solutions for this building. It is also necessary to pay attention to the integration into the existing urban environment, as well as to develop a scheme for organizing the territory adjacent to the house. The public space in front of the building should be aesthetically pleasing and attract the attention of others. Large areas should be arranged for landscaping the object, not forgetting about small architectural forms, such as benches and urns for worshipers.

When a building is located in the suburbs of a large city, for example, Moscow, it becomes expedient to erect it from wood. This material is environmentally friendly and in demand in suburban construction. It is proposed to use a wooden frame with a pitched roof (Figure 6).

Since there are no objects of the symbol of faith (old icons, crosses, etc.) in the Quaker meetings house, the choice of engineering equipment for such a building will be much easier than, for example, for an Orthodox church.

Internal cold and hot water supply must be designed in the building [21-23]. Water is supplied through the piping to the mixers, which are installed in the washrooms. The pipe entrance to the building is laid below the freezing depth and enters the basement, going up and passing into the risers. The water must be of drinking quality, because the building has kitchen and dining areas.

Water can be supplied either from a centralized water supply system, or taken from a well, or a shaft well (local water supply system). For the functioning of hot water supply, the system can be connected either to centralized networks, or have its own (local) water heating systems powered by natural gas or electricity.

In buildings with an area of less than $100 \mathrm{~m}^{2}$, fire-fighting water supply is not designed, however, with a feasibility study, it is possible to design a deluge fire extinguishing system that works in conjunction with fire alarm smoke detectors [14]. Water for fire-fighting is also supplied from the internal water supply system.

The sewage system is designed for household use and includes washbasins, toilets, sinks and sewer pipes. It is advisable to install food waste shredders under the sinks. They crush various kitchen (food) waste, which is then washed into the internal household sewer system. This will reduce the cost of waste disposal.

Stove heating can be used to heat the Quaker meetings house, but it can be difficult due to the need for daily kindling of firewood, as well as the need to order them. In the presence of main gas, it becomes advisable to use gas heating devices.

Outside, a system of external gutters is being designed, which will collect rain and meltwater from the pitched roof and transport it to the blind area.

It is advisable to organize the drainage of atmospheric and ground water from the builtup area. This will solve a large number of problems associated with flooding of the land around the building.

Power supply and ventilation systems are also designed, and an air conditioning system can be installed if necessary.

The issues of engineering equipment should also be strictly linked to the space-planning solutions of the premises. 


\section{Discussion}

The above examples of space-planning solutions, as well as the necessary engineering equipment with the planning of the adjacent territory, will fully allow creating a convenient and comfortable house for holding prayer meetings, built taking into account modern recommendations.

You should also pay attention to the implementation of a security system, which consists not only in designing a fire-fighting water supply system, but also a video surveillance and access control system to create a comfortable living environment.

Also, this building should be designed taking into account energy and resource conservation. For this, solar panels installed on the roof of a prayer house can be used, thanks to which the accumulation and consumption of electrical energy for the needs of the building will be produced.

The results obtained allow the design and construction of Quaker meetings houses, taking into account modern requirements of convenience and comfort, but without any expensive excesses, keeping the main goal of the Quakers - worship accessibility for all people, regardless of their income and social status in society.

It will also be possible to talk about the emergence and development of Quaker architecture, based on classical understandings of simplicity and grace, accessible to people not only in Russia, but also abroad.

\section{Conclusions}

Based on the study of various literary sources, as well as the peculiarities of the Quaker prayer meetings, it was decided to design and develop space-planning solutions for buildings where representatives of Christian Protestantism with modern convenience and comfort can calmly and naturally conduct their services.

Space-planning solutions were developed for the objects of the Quaker religious building, which include the following blocks: block of premises of the entrance part; eating area; a block of kitchen facilities; administrative premises and a block of household premises; area for prayer meetings.

Also, recommendations are given on the construction of engineering equipment of buildings, taking into account modern requirements for comfort, as well as proposals for the development of planning solutions for the organization of the adjacent territory.

Further study and development of the subject is possible towards the development of various types of building facades, taking into account modern requirements for aesthetics.

\section{References}

1. M. Abbott, M.E. Chijioke, P. Dandelion, J.W. Oliver, eds., Historical Dictionary of The Friends (Quakers) (Scarecrow Press, June 2003)

2. A.L. Gel'fond, Architectural design of public buildings and structures (Arhitektura-S, Moscow, 2006)

3. T.G. Maklakova, History of architecture and construction technology. The architecture of the industrial era in architecture (ASV, Moscow, 2003)

4. I.A. Sinyanskij, N.I. Maneshina, Typology of buildings (Izdatel'skij centr «Akademiya», Moscow, 2014)

5. L.E. SHashkova, Fundamentals of rational design of public buildings (Vologodskij gosudarstvennyj universitet, Vologda, 2018) 
6. G.V. Esaulov, Sustainable architecture: from principles to development strategy, Vestnik TGASU 6, 9-14 (2014)

7. N.W. Roberts, A.D. Leo, Building type basics for places of worship (John Wiley \& Sons, Inc., Hoboken, New Jersey, 2004)

8. T. Barrie, Spiritual Path, sacred place. Myth, ritual, and meaning in architecture (Shambhala, Boston, 1996)

9. J.H. Kilde, Sacred Power, Sacred Space: An Introduction to Christian Architecture and Worship (Oxford University Press, New York, 2008)

10. R. Klanten, F. Lukass, eds., Closer to God: Religious Architecture and Sacred Spaces (Gestalten, Berlin, 2010)

11. S. Yiling, Is Religious Architecture Still Relevant? ArchDaily. 12 Apr (2018). https://www.archdaily.com/891984/is-religious-architecture-still-relevant

12. A. Crompton, The Architecture of Multifaith Spaces: God Leaves the Building, The J. of Architecture 184 (2013)

13. J. Bermudez, Transcending Architecture: Contemporary Views on Sacred Space (The Catholic University of America Press, USA, 2015)

14. L.A. Viktorova, On the set of rules "Religious buildings. Fire safety requirements", BST: Byulleten stroitelnoj tekhniki 11 (915) 28-35, 2010

15. Yu.V. Kurmaz, The role of the architect in the symbolic design of the cult space model and the solution of the cult building shape, Globalnyj nauchnyj potencial 11 (56) 161163 (2015)

16. R. Homan, The Aesthetic of Friends' Meeting Houses, Quaker Studies 11/1 115-128 (2006)

17. W. Alexander, Observations on the Construction and Fitting Up of Meeting-Houses, etc. for Public Worship. (Wm Alexander, York, England, 1820)

18. T.Ch. Matlack, Brief Historical Sketches Concerning Friends' Meetings (Moorestown NJ, 1938)

19. S.B. Hinshaw, The Evolution of Quaker Meeting Houses in North America 1670-2000 (Masters Thesis) (University of Pennsylvania, Philadelphia, PA, 2001)

20. D. Tvaryanas, The New Jersey Quaker Meeting House: A Typology and Inventory (Masters Thesis) (University of Pennsylvania, Philadelphia, PA, 1993)

21. A.A. Wael, S. Weldy, Integration of building service systems in architectural design, J. of Inform. Technol. in Constr. 25 109-122 (2020)

22. L. Jack, S. Vaughan, Comparison of design methods for water supply pipework: A case study analysis, in Proceedings of the 41st CIBW062 International Symposium of Water Supply and Drainage Systems for Buildings, 17-20 August 2015, Beijing, China (2015)

23. A.A. Ostavnov, Water supply and sanitation of public buildings (AVOK-PRESS, Moscow, 2011) 